\title{
The Agricultural Potential of Northwestern Canada and Alaska and the Impact of Climatic Change
}

\author{
PETER F. MILLS ${ }^{1}$
}

\author{
(Received 14 December 1992; accepted in revised form 13 September 1993)
}

\begin{abstract}
Climate change studies have indicated the potential for increased drought in the southern Canadian prairies, and with this the potential exists for a northward shift in agricultural production areas. In order to assess the potential for agriculture, the arable soils of northwestern Canada (approximately north and west of $55^{\circ} \mathrm{N}$ latitude and $110^{\circ} \mathrm{W}$ longitude) and Alaska were summarized. The study area was divided into several sub-regions or major land resource areas (MLRA) within which the soils with potential for agricultural use were identified through existing soil surveys. These surveys indicate an area of greater than $57 \mathrm{M}$ hectares (Ha) of potentially arable land, which could be used for either annual cropping or grazing on perennial forages, according to the Canada Land Inventory class 1-5 criteria. The climatic limitations for each MLRA were assessed separately through the use of Climate Classification Software. These limitations were then applied to the $57 \mathrm{M} \mathrm{Ha}$ of potentially arable land identified earlier, with the result that the area was rated as overall class 5 climate, limited primarily by heat, and the size of the area was reduced to $39.2 \mathrm{M} \mathrm{Ha}$. The impact of a $2 \times \mathrm{CO}_{2}$ changed climate on this area was then assessed by the use of climatic data generated with the Canadian Climate Centre, Global Circulation Model. These data show a much improved climatic capability for agriculture, being substantially warmer and somewhat drier. The overall climate class increased to a rating of 3 , and $55.3 \mathrm{M} \mathrm{Ha}$ of arable land were shown to be potentially available in the study area.
\end{abstract}

Key words: climate change, agriculture, soil, resource assessment, northwestern Canada, Alaska

RÉSUMÉ. Des études sur le changement climatique ont révélé que la sécheresse pourrait s'aggraver dans le sud de Prairies canadiennes et entraîner une migration vers le nord des zones de production agricole. Pour vérifier cette hypothèse, on a regroupé les sols arables du nord-ouest du Canada (situés à peu près au nord et à l'ouest du $55^{\mathrm{e}}$ degré de latitude nord et du $110^{\circ}$ degré de longitude ouest) et de l'Alaska pour en évaluer les aptitudes agricoles. La région à l'étude a été répartie en plusieurs sous-régions ou zones principales de sols (ZPS) dont on a déterminé, à l'aide des prospections pédologiques existantes, les aptitudes à l'agriculture. Ces prospections révèlent qu'une superficie de plus de 57 millions d'hectares de terre potentiellement cultivable pourrait servir à la culture de plantes annuelles ou à la paissance de plantes fourragères vivaces selon les critères d'évaluation des sols de classe 1 à 5 de l'Inventaire des terres du Canada (ITC). On a évalué séparément les restrictions climatiques de chaque ZPS au moyen du Logiciel de classification climatique. On a ensuite appliqué ces restrictions aux 57 millions d'hectares de terre potentiellement cultivable susmentionnés. Selon cette opération, la superficie en question entre dans la grande classe climatique 5, limitée principalement par la chaleur; il a done fallu la réduire à 39,2 millions d'hectares. On a ensuite évalué l'effet d'un changement climatique (le double de la concentration de $\mathrm{CO}_{2}$ ) sur cette superficie à l'aide des données climatiques produites par le Modèle de circulation atmosphérique à l'échelle mondiale du Centre climatologique canadien. Ces données révèlent une grande amélioration des possibilités du climat pour l'agriculture, qui devient beaucoup plus chaud et un peu plus sec. La superficie entre alors dans la classe climatique 3 et 55,3 millions d'hectares de terre arable deviennent alors potentiellement accessibles dans la région à l'étude.

Mots clés : changement climatique, agriculture, sol, évaluation des ressources, nord-ouest du Canada, Alaska

\begin{abstract}
РЕФЕРАТ. Изучение изменений хлимата показло потенциальную возмохность сильной засухи в юхвых районах канадских прерий, в связи с чем мохно охидать сдвига сельскохозкйственного производствл в северном ваправлевии. Для одевки здачедия этого сдвига для сельсхого хозяћства было проведено суммарное обследование пахотных эемель Северо-Западноћ Канады (примерво х северу от $55^{\circ}$ с.ш. $и x$ западу от $110^{\circ}$ з.д.) и Алдски. Изудемая площадь была разделева на вескольхо подрайовов, или "основных үчастков земельвых ресурсов", в пределах хоторых попны, потевцианьво пригоднье для сельсхого хозя⿰ств, бнли идевтифидированы путем использовавия имеюшихся дандых почвевных съемок. Эти съемхи погазивајот наличие свыпе 57 млн. га потевдиапьно пахотной земли, готорые мотут бкть испольэовавы либо для ехегодвото вырацивавия сельскохозяйственных культур, либо для выпаса скота ва мвоголетних кормах в соответстви с хритериями Земельвого реестра Кавады, классы 1-5. Климатические огранидепия были оценены для гахдого из основных участхов земельвых ресурсов отдельно с помощью компьютервоһ программы хлассификации климата. Эти огравичевия были затем прилохены $\mathrm{x}$ выявленным равее 57 млғ. та потевциально пахотної земли, в результате пего эта пнощадь бшла отнесева в делом х 5-у хлиматическому классу, огравичевному главвым образом теплом, и размер площади был

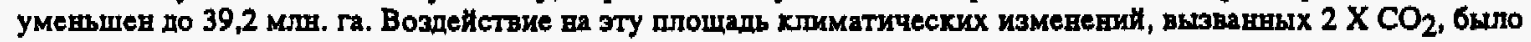
оденено путем использовавия климатических даныых, получевньх с помощью модели глобальноћ пиргупяии в Кавадском ктматическом девтре. Эти данвње показыва ют значительно улучшившиеся, сушествепо более теплье и вескольхо более сухие климатические условия для сельсхого хозяЙтва. Обший хлиматический хласс возрос до 3 , и ва изучевной площади было уставовлево потенциальвое налитие 55,3 млв. та пахотной земли.
\end{abstract}

Клодевье слова: изменение климата, сельское хозяһ̆ство, подва, одепка ресурсов, Северо-Западная Канада, Argcka.

\footnotetext{
${ }^{1}$ Agrometeorologist, Northern Agriculture Research Centre, Agriculture and Agri-Food Canada, P.O. Box 29, Beaverlodge, Alberta, Canada TOH OCO

OThe Arctic Institute of North America
} 


\section{INTRODUCTION}

The land area of northwestern Canada and Alaska that has potential for agricultural uses has been widely debated for over 20 years (Harris et al., 1972; Eley and Findlay, 1977). These debates have dwelt on what the potential areas are and if the primary limiting factor is soil or climate. The arable soils of the Yukon Territory, the western portion of the Northwest Territories, Alaska and the northern portions of Alberta and British Columbia have generally been perceived as having excessively thin topsoil horizons, having low fertility and being located in widely dispersed pockets along primary river valleys such that they were not worthy of development (Beattie $e t a l$, 1981). In fact, according to the original soil surveyors there are substantial areas of land which are suitable for agricultural use.

The existing soil resources for agricultural purposes have been inventoried on a region or basin basis by a number of different authors (Northern Research Group, 1978; Rostad and Kozak, 1977). These inventories have been done over a period of approximately 45 years, largely under the auspices of exploratory soil surveys, and have used criteria such as the Canada Land Inventory System (CLI) (Canada Land Inventory, 1969) and variations of the older Land Classification System or Storie Index (Storie, 1933). Since the surveys have been done independently, divergent assessments have resulted from different criteria being used and improved knowledge of the region being incorporated over time. Early assessments of selected areas in Alaska identified approximately $0.8 \mathrm{M}$ hectares $(\mathrm{Ha})$ of arable land. By 1974 , more comprehensive studies dramatically increased this figure to 6.2 M Ha (Rieger, 1974), then 7.5 M Ha (Alaska Rural Development Council, 1983) and finally the currently accepted value of 8.2 M Ha of "fair" or better agricultural land, as defined in the Exploratory Soil Survey of Alaska (Rieger et al., 1979). Due to the widespread publication and dated nature of the detailed soil surveys conducted within the study area, there have been few efforts to summarize them into a single document (Harris et al., 1972; Miller, 1984).

In light of recent developments in the area of climatic change, there is increasing agreement that a warmer climate is inevitable and there will be increasing pressures on northern development (Magill and Geddes, 1988).

The objective of this study is to tabulate the total soil resource, defined in the original soil surveys, over the study area extending north and west from approximately $55^{\circ} \mathrm{N}$ latitude and $110^{\circ} \mathrm{W}$ longitude (Fig. 1). Subsequently, the capability of the existing climate of the study area to support agriculture is assessed and the effect of a $2 \times \mathrm{CO}_{2}$ atmosphere on the temperature and precipitation regimes is determined. The study then assesses the impact of the projected $2 \times \mathrm{CO}_{2}$ temperature and precipitation regimes on the climatic suitability for agriculture and the extent of the previously defined potentially arable lands in the study area.

\section{MATERIALS AND METHODS}

The spatial extent of potentially arable lands in northwestern North America was assessed by defining the overall area of study and subsequently breaking that down into manageable

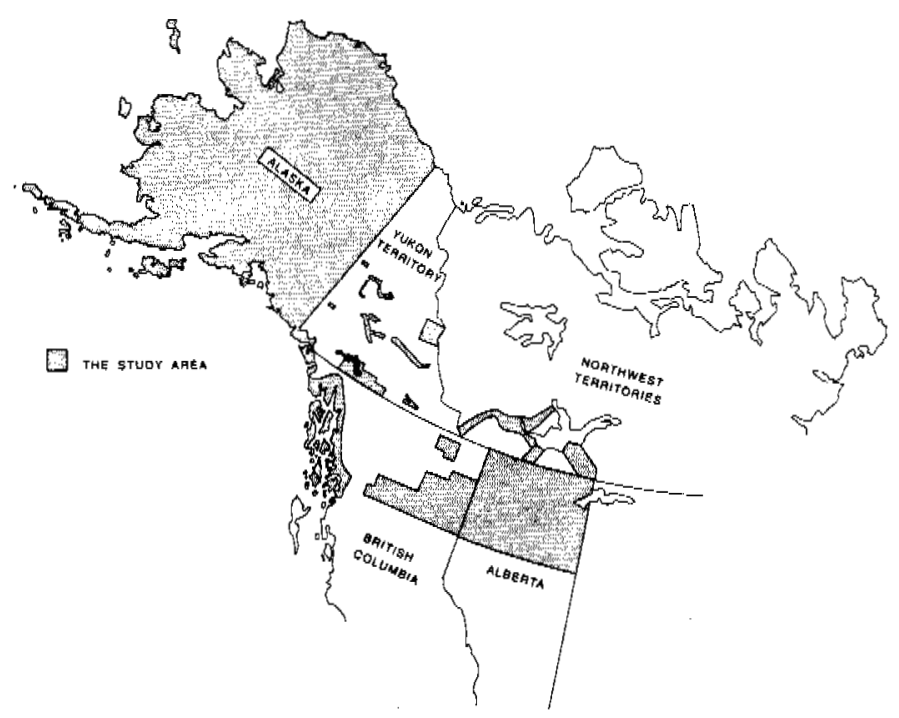

FIG. 1. The study area.

zones referred to as major land resource areas (MLRAs). Representative meteorological sites were also selected for each MLRA. The literature was then examined for existing soil surveys or related documentation that could provide an assessment of the extent and suitability of the potentially arable lands for each MLRA. The primary system used in these soil survey reports is a soil class or soil capability class for agriculture. This approach defines criteria for such parameters as fertility, infiltration, stoniness, slope and soil texture and then integrates the results for each soil series or soil type into a numeric class. Depending on the classification scheme used, there can be from 3 to 7 classes representing excellent to non-arable soils.

Due to the differences over time and between the two countries involved, it was necessary to develop a system to cross correlate the various rating systems used and reduce each to one common classification system. The Canada Land Inventory System was chosen for this purpose because it was the predominant system used in the literature and with its seven classes it became easier to fit other systems into it. The correlation matrix shown in Table 1 is based on the published subjective definitions used for the different surveys involved.

One obvious limitation of this approach was the problem of determining the matching classes when a 3- or 4-class system was incorporated into a 7-class system. For purposes of this study, wherever there was a choice of 2 classes the soil series in question was placed in the lower quality class. For this paper, arable land is defined as soil capability classes 1-4, which are suitable for annual cropping, and class 5 , which is suitable for perennial forages or grazing and has some potential for improvement. The following qualitative class definitions are used by the CLI and are used within this study for the definition of both soil and climate capability.

Arable: Class 1, excellent agricultural potential for all common crops. Class 2, good potential for common annual crops. Class 3, fair potential for common annual crops. Class 4 , suitable for grazing, perennial crops or hardy annual 
TABLE 1. Soil ratings correlation matrix

\begin{tabular}{|c|c|c|c|c|c|c|c|}
\hline Soil rating system & \multicolumn{5}{|c|}{ Arable } & \multicolumn{2}{|c|}{ Non-arable } \\
\hline Canada Land Inventory & 1 & 2 & 3 & 4 & 5 & 6 & 7 \\
\hline Land capability classes (mid-1950s) & 1 & 2 & 3 & 4 & 5 & \multirow{2}{*}{\multicolumn{2}{|c|}{$\frac{6}{\text { Non-arable (forest) }}$}} \\
\hline Land classes (mid-1940s) & \multicolumn{2}{|c|}{ Arable } & \multicolumn{3}{|c|}{ Temporarily non-arable } & & \\
\hline Productivity soil ratings (early 1960s) & \multicolumn{2}{|c|}{ Good to very good } & $\begin{array}{l}\text { Fairly good } \\
\text { to good }\end{array}$ & $\begin{array}{c}\text { Fair to } \\
\text { fairly good }\end{array}$ & $\begin{array}{l}\text { Poor to } \\
\text { fair }\end{array}$ & \multicolumn{2}{|c|}{ Pasture or woodland } \\
\hline Alberta exploratory soil surveys (late $1950 \mathrm{~s}$ ) & \multicolumn{3}{|c|}{ Arable } & \multicolumn{2}{|c|}{ Doubtful } & \multicolumn{2}{|c|}{ Pasture and woodland } \\
\hline Exploratory soil survey of Alaska & \multicolumn{2}{|c|}{ Good } & \multicolumn{2}{|c|}{ Fair } & Poor & \multicolumn{2}{|c|}{ Unsuitable } \\
\hline
\end{tabular}

crops. Class 5, suitable for grazing with potential for improvement.

Non-arable: Class 6, suitable for native grazing with no potential for improvement. Class 7, no agricultural potential of any type.

The study area was subdivided into MLRAs based on both political and physiographic boundaries to aid in the delineation of the agricultural potential of each area. The political delineation was required largely on the basis of the federal, provincial, territorial or state agency that did the original soil survey work, while the physiographic delineation was based on the actual surveys or recognized areas (Department of Mines and Technical Surveys, 1957). Once the correlations were established, data were tabulated according to their MLRA and applicable CLI suitability class.

In addition to the inventory of the potentially arable soils of the study area, an attempt was undertaken to identify the climate for each MLRA. Representative meteorological sites for each MLRA were selected. These sites, along with their locations, are listed in Table 2. Mean monthly air temperature and precipitation data for each of the representative sites under the current climate conditions $\left(1 \times \mathrm{CO}_{2}\right)$ were extracted from Canadian and United States summaries (Atmospheric Environment Service, 1982a; National Oceanic and Atmospheric Administration, 1988) of long-term climatic data. These data were typically 30-year normals, although some newer sites were less (Table 3 ). The data were then used as direct input into version 2.0 of the Climate Classification System (CCS) computer program originally developed for use in Alberta (Alberta Agrometeorology Advisory Committee, 1987). This has recently been updated and coded for use on a personal computer (Mills, 1992).

The CCS utilizes mean monthly air temperature and precipitation data to calculate a numeric rating of the climate's suitability for agriculture based on an energy term, a moisture term and several modifying factors. The energy term is based upon the growing degree day $\left(5^{\circ} \mathrm{C}\right.$ base) concept and is modified to consider day length and the diurnal temperature range to generate the final energy term, the effective growing degree days (EGDD). The moisture term is based on the concept of precipitation (P) minus the potential evapotranspiration (PE). The resulting P-PE value is modified by a crop water demand curve based on annual cereal grains. Separate modifying factors considered are spring and fall moisture excesses affecting seeding and harvest operations, hail and the susceptibility of the site to atypically early fall frosts. The numeric values generated for the energy and moisture terms are used to determine if heat or moisture is the greatest limiting factor. The modifying factors are then applied, and the resulting numeric value is converted into one of seven corresponding capability classes. The CCS utilizes the same class definitions that are found in the CLI soil capability system.

The impact of climatic change on each sites' climate capability rating was assessed through the use of two condensed data sets of monthly Global Circulation Model (GCM) data from the second generation GCM developed by the Canadian Climate Centre (Canadian Climate Centre, 1991). This version of the GCM incorporates several enhancements over its predecessor. In addition to the increased resolution provided by a $3.75^{\circ}$ latitude $\times 3.75^{\circ}$ longitude grid, ocean mixing, sea ice thermodynamics and cloud parameterization are included in the model. Improved algorithms for solar and terrestrial radiative heating and land surface processes are also incorporated (McFarlane et al., 1992). This model was chosen in preference to other GCMs such as the National Centre for Atmospheric Research, the United Kingdom Meteorological Office or the Goddard Institute of Space Studies models both due to data availability and because in comparison tests this model has produced fewer extreme results than some of the others (Intergovernmental Panel on Climate Change, 1990).

As indicated earlier, this model produced two complete condensed databases of monthly values on a $3.75^{\circ}$ grid for a wide range of surface and upper air parameters. The first database represents the $1 \times \mathrm{CO}_{2}$ data, while the second represents the future projected $2 \times \mathrm{CO}_{2}$ atmosphere. The GCM undertakes a complete three-dimensional treatment of the atmosphere; however, for this work only the initial and final conditions have been used and the behaviour of the atmosphere during the transition from the $1 \times \mathrm{CO}_{2}$ to the $2 \times \mathrm{CO}_{2}$ status has not been considered. Since the GCM output consisted of grid cell data, it was necessary to adapt these values to the site-specific meteorological sites chosen earlier. This was done by comparing the two databases and establishing changes for each grid cell over the study area. In order to maintain localized topographic influences such as slope, aspect and elevation, these changes were then applied to the mean monthly temperature and precipitation data for each of the representative sites that existed within that cell. Temperature values were adjusted through the addition of the temperature differences, while precipitation was adjusted on the basis of a percentage change. In no case were there more than two sites within one cell. A new database of surface climatological data for each of the representative sites is shown in Table 4. 
TABLE 2. Representative meteorological sites for major land resource areas

\begin{tabular}{|c|c|c|c|c|}
\hline Major land resource area & Site & Latitude & Longitude & Elevation (m) \\
\hline \multicolumn{5}{|l|}{ Southern Alaska } \\
\hline Southeastern Alaska & Sitka & $57^{\circ} 04^{\prime}$ & $135^{\circ} 21^{\prime}$ & 5 \\
\hline South central Alaska mountains & Yakutat & $59^{\circ} 31^{\prime}$ & $139^{\circ} 40^{\prime}$ & 9 \\
\hline Cook Inlet - Susitna lowland & Anchorage & $61^{\circ} 10^{\prime}$ & $150^{\circ} 01^{\prime}$ & 35 \\
\hline Alaska Peninsula and Southwestern islands & Kodiak & $57^{\circ} 45^{\prime}$ & $152^{\circ} 30^{\prime}$ & 4 \\
\hline \multicolumn{5}{|l|}{ Interior Alaska } \\
\hline Copper River plateau & Eureka Lodge & $61^{\circ} 57^{\prime}$ & $147^{\circ} 10^{\prime}$ & 1015 \\
\hline Alaska Range & McKinley Park & $63^{\circ} 45^{\prime}$ & $148^{\circ} 58^{\prime}$ & 631 \\
\hline Interior Alaska lowlands & Fairbanks & $64^{\circ} 49^{\prime}$ & $147^{\circ} 52^{\prime}$ & 133 \\
\hline Kuskokwim highlands & Dillingham & $59^{\circ} 11^{\prime}$ & $158^{\circ} 27^{\prime}$ & 24 \\
\hline Interior Alaska highlands & Hughes & $66^{\circ} 04^{\prime}$ & $154^{\circ} 14^{\prime}$ & 168 \\
\hline \multicolumn{5}{|l|}{ Arctic and western Alaska } \\
\hline Norton Sound highlands & Unalakleet & $63^{\circ} 53^{\prime}$ & $160^{\circ} 48^{\prime}$ & 5 \\
\hline Western Alaska coastal plains and deltas & Bethel & $60^{\circ} 47^{\prime}$ & $161^{\circ} 48^{\prime}$ & 3 \\
\hline Bering Sea islands & Mekoryuk & $60^{\circ} 23^{\prime}$ & $166^{\circ} 12^{\prime}$ & 14 \\
\hline Brooks Range & Anaktuvuk Pass & $68^{\circ} 10^{\prime}$ & $151^{\circ} 46^{\prime}$ & 640 \\
\hline Arctic foothills & Umiat & $69^{\circ} 22^{\prime}$ & $152^{\circ} 08^{\prime}$ & 81 \\
\hline Arctic coastal plain & Barrow & $71^{\circ} 18^{\prime}$ & $156^{\circ} 47^{\prime}$ & 9 \\
\hline \multicolumn{5}{|l|}{ Alberta } \\
\hline Upper Peace & Beaverlodge & $55^{\circ} 12^{\prime}$ & $119^{\circ} 23^{\prime}$ & 745 \\
\hline Lower Peace & Fort Vermilion & $58^{\circ} 23^{\prime}$ & $116^{\circ} 04^{\prime}$ & 279 \\
\hline \multicolumn{5}{|l|}{ British Columbia } \\
\hline North central interior & Smithers A & $54^{\circ} 49^{\prime}$ & $127^{\circ} 11^{\prime}$ & 523 \\
\hline Northern B.C. - Ft. Nelson, Liard & Fort Nelson A & $58^{\circ} 50^{\prime}$ & $122^{\circ} 35^{\prime}$ & 382 \\
\hline Prince George & Prince George A & $53^{\circ} 53^{\prime}$ & $122^{\circ} 41^{\prime}$ & 676 \\
\hline Peace & Fort St. John A & $56^{\circ} 15^{\prime}$ & $120^{\circ} 50^{\prime}$ & 674 \\
\hline \multicolumn{5}{|l|}{ Yukon } \\
\hline Klondike Plateau & Dawson & $64^{\circ} 04^{\prime}$ & $139^{\circ} 26^{\prime}$ & 324 \\
\hline Lewes plateau & Fort Selkirk & $62^{\circ} 49^{\prime}$ & $137^{\circ} 22^{\prime}$ & 454 \\
\hline Liard plain & Watson Lake & $60^{\circ} 07^{\prime}$ & $128^{\circ} 49^{\prime}$ & 690 \\
\hline Pelly plateau & Ross River & $61^{\circ} 58^{\prime}$ & $132^{\circ} 26^{\prime}$ & 705 \\
\hline Teslin plateau & Whitehorse & $60^{\circ} 43^{\prime}$ & $135^{\circ} 04^{\prime}$ & 703 \\
\hline Takhini-Dezadeash & Carcross & $60^{\circ} 11^{\prime}$ & $134^{\circ} 42^{\prime}$ & 660 \\
\hline Wellesley plain & Snag A & $62^{\circ} 22^{\prime}$ & $140^{\circ} 24^{\prime}$ & 587 \\
\hline \multicolumn{5}{|l|}{ Northwest Territories } \\
\hline Slave River lowlands & Fort Smith A & $60^{\circ} 01^{\prime}$ & $111^{\circ} 57^{\prime}$ & 203 \\
\hline Liard valley and upper Mackenzie & Fort Simpson A & $61^{\circ} 45^{\prime}$ & $121^{\circ} 14^{\prime}$ & 169 \\
\hline Mackenzie River & Wrigley A & $63^{\circ} 12^{\prime}$ & $123^{\circ} 26^{\prime}$ & 150 \\
\hline Hay River & Hay River A & $60^{\circ} 50^{\prime}$ & $115^{\circ} 47^{\prime}$ & 166 \\
\hline
\end{tabular}

$\mathrm{A}=$ aimport.

Since the GCM data supplied were on a monthly time base, they did not provide daily information for the date of the start of the growing season or the date of the first fall frost used in the CCS. Data for the date of the first fall frost were generated through the use of TABLECURVE ${ }^{\circ}$ curve fitting software. This was done by fitting a model relating the longterm data for the date of the first fall frost $\left(\leq 0^{\circ} \mathrm{C}\right)$ to the daily mean minimum temperature for a number of sites in the area (Atmospheric Environment Service, 1982b). The intercept of the regression surface between mean minimum temperature and the date of the first fall frost was found to be $5.16^{\circ} \mathrm{C}$. The $2 \times \mathrm{CO}_{2}$ mean minimum monthly temperature data for each of the sites used in this study were then input into the TABLECURVE ${ }^{\oplus}$ software and evaluated for the date at which the resulting curve crossed the previously established $5.16^{\circ} \mathrm{C}$ threshold representative of the date of the first fall frost. The start of the growing season was calculated by an algorithm within the CCS as the first of five consecutive days after 15 March with daily mean temperatures of $5.0^{\circ} \mathrm{C}$ or greater. Error analysis of the CCS program has shown that due to the very low energy levels being considered at either of these times of year, an error of up to a week in these dates produces errors of only about $1 \%$ in the calculated energy term for the site, the EGDD. The climate capability class ratings subsequently derived from the CCS were applied to each MLRA, and those with a rating of 6 or 7 were dropped on the basis that the climate for that MLRA would not support agriculture. Summation of the remaining areas provided the measure of potentially arable land under that climate or atmosphere scenario.

\section{RESULTS}

\section{Potentially Arable Soils}

The summary of the potentially arable lands currently recognized in the study area is shown in Table 5. As can 
TABLE 3. $1 \times \mathrm{CO}_{2}$ Mean monthly climate data

\begin{tabular}{|c|c|c|c|c|c|c|c|c|c|c|c|c|c|c|c|c|c|c|c|c|c|c|}
\hline \multirow[b]{2}{*}{ Site } & \multicolumn{7}{|c|}{ Precipitation (mm) } & \multicolumn{7}{|c|}{ Maximum temperature $\left({ }^{\circ} \mathrm{C}\right)$} & \multicolumn{7}{|c|}{ Minimum temperature $\left({ }^{\circ} \mathrm{C}\right)$} & \multirow[b]{2}{*}{ Frost } \\
\hline & Apr & May & Jun & Jul & Aug & Sep & $\overline{\mathrm{Oct}}$ & $\overline{\text { Apr }}$ & May & Jun & Jul & Aug & Sep & Oet & Apr & May & Jun & Jul & Aug & Sep & $\overline{\mathrm{Oct}}$ & \\
\hline$\overline{\text { Sitka }}$ & $\overline{129.2}$ & 119.3 & 90.9 & $\overline{112.5}$ & 169.6 & 264.1 & 346.4 & 8.7 & $\overline{11.8}$ & $\overline{14.1}$ & $\overline{16.2}$ & $\overline{16.7}$ & $\overline{14.6}$ & $\overline{10.3}$ & $\overline{2.0}$ & $\overline{4.9}$ & $\overline{8.0}$ & $\overline{10.4}$ & $\overline{10.9}$ & 8.7 & 5.3 & Nov 02 \\
\hline Yakutat & 218.9 & 231.6 & 141.2 & 209.8 & 255.5 & 400.8 & 511.0 & 6.2 & 9.8 & 13.1 & 15.3 & 15.4 & 12.9 & 8.4 & -1.8 & 2.1 & 6.2 & 8.6 & 7.9 & 5.1 & 1.3 & \\
\hline Anchorage & 16.7 & 14.5 & 27.4 & 50.0 & 53.6 & 62.2 & 43.9 & 5.9 & 12.3 & 16.6 & 18.4 & 17.3 & 12.9 & 4.9 & -2.1 & 3.5 & 8.3 & 10.6 & 9.6 & 5.1 & -2.0 & 25 \\
\hline Kodiak & 122.9 & 196.3 & 85.6 & 99.3 & 132.3 & 193.0 & 253.7 & 6.3 & 9.1 & 13.4 & 15.2 & 16.1 & 13.3 & 8.4 & 0.4 & 3.3 & 6.3 & 8.9 & 9.2 & 6.6 & 1.8 & Sep $30 \mathrm{E}$ \\
\hline Eureka Lodge & 11.4 & 28.4 & 77.0 & 69.9 & 53.6 & 33.0 & 21.6 & 0.1 & 8.2 & 14.7 & 16.4 & 14.9 & 9.2 & -0.9 & -11.2 & -2.8 & 3.3 & 5.3 & 4.4 & 0.1 & -9.3 & Aug $16 \mathrm{E}$ \\
\hline McKinley Park & 9.7 & 20.8 & 62.5 & 77.7 & 60.5 & 36.3 & 23,4 & 3.4 & 11.7 & 17.6 & 19.1 & 16.7 & 10.6 & 0.5 & -9.4 & -1.7 & 3.9 & 5.7 & 4.2 & -1.0 & -9.9 & Aug 17 \\
\hline Fairbanks & 17.3 & 14.5 & 29.5 & 54.4 & 55.9 & 62.7 & 41.9 & 4.9 & 15.1 & 21.2 & 22.1 & 19.2 & 12.4 & 0.3 & -6.9 & 2.9 & 9.2 & 10.7 & 8.1 & 1.9 & -8.1 & Sep 06 \\
\hline Dillingham & 29.5 & 40.1 & 44.2 & 70.9 & 99.8 & 87.1 & 65.8 & 3.4 & 10.4 & 15.7 & 17.7 & 16.7 & 12.9 & 5.4 & -5.1 & 0.8 & 5.2 & 7.7 & 7.7 & 4.1 & -2.7 & Sep $12 \mathrm{E}$ \\
\hline Hughes & 9.9 & 11.7 & 24.4 & 49.8 & 63.0 & 33.5 & 27.2 & 1.8 & 12.2 & 20.4 & 21.3 & 17.7 & 10.7 & -0.9 & -12.1 & 0.3 & 8.1 & 9.9 & 6.8 & 0.8 & -8.9 & Aug $29 \mathrm{E}$ \\
\hline Unalakleet & 12.2 & 16.3 & 29.7 & 59.9 & 90.9 & 57.4 & 25.7 & -1.3 & 7.6 & 12.7 & 16.2 & 15.0 & 10.5 & 0.8 & -10.4 & -0.9 & 5.3 & 8.8 & 7.7 & 2.5 & -6.0 & Sep $06 \mathrm{E}$ \\
\hline Bethel & 18.0 & 20.3 & 34.0 & 53.6 & 87.9 & 56.4 & 32.8 & -0.2 & 9.3 & 14.9 & 16.7 & 15.2 & 11.1 & 2.0 & -9.3 & -0.1 & 5.7 & 8.5 & 7.9 & 3.4 & -4.6 & Sep 17 \\
\hline Mekoryuk & 0.3 & 0.0 & 0.0 & 0.8 & 27,2 & 19.3 & 9.9 & -1.8 & 2.9 & 11.9 & $13.0 \mathrm{E}$ & 12.1 & 11.3 & 3.6 & -10.5 & -7.1 & 4.6 & $7.2 \mathrm{E}$ & 3.2 & -0.1 & -2.3 & $\operatorname{Sep} 12 \mathrm{E}$ \\
\hline Anaktuvuk Pass & 14.7 & 13.0 & 37.3 & 45.0 & 39.1 & 25.9 & 19.6 & -10.1 & 4.2 & 13.9 & 16.0 & 11.7 & 3.6 & -9.5 & -20.4 & -6.4 & 2.3 & 4.8 & 1.8 & -4.2 & -16.7 & Jul $26 \mathrm{E}$ \\
\hline Umiat & 5.3 & 3.3 & 20.3 & 17.0 & 26.9 & 13.2 & 15.0 & -13.7 & -1.3 & 12.5 & 18.1 & 14.2 & 4.9 & -7.8 & -25.8 & -9.8 & 2.2 & 5.5 & 3.2 & -3.1 & -15.8 & Aug $08 \mathrm{E}$ \\
\hline Barrow & 5.3 & 4.1 & 9.4 & 21.8 & 24.9 & 15.0 & 14,0 & -14.8 & -4.7 & 3.0 & 7.0 & 5.8 & 1.0 & -7.3 & -22.7 & -10.1 & -1.5 & 0.7 & 0.8 & -2.6 & -12.5 & Aug 09 \\
\hline Beaverlodge & 19.3 & 39.0 & 68.4 & 64.0 & 63.8 & 42.0 & 28.6 & 7.9 & 15.6 & 19.2 & 21.6 & 20.5 & 15.3 & 9.5 & -2.7 & 3.1 & 6.9 & 8.8 & 7.8 & 3.7 & -0.7 & Sep 07 \\
\hline Fort Vermilion & 16.4 & 320 & 50 & 66.3 & 52.7 & 34.7 & 25.6 & 7.6 & 16.8 & 21.1 & 22. & 21.1 & 14.5 & 6.7 & -4.5 & 3.4 & 7.7 & 10.1 & 8.3 & 2.9 & -3.0 & Sep 03 \\
\hline Smithers & 17.6 & 30.0 & 40.0 & 45.9 & 43.7 & 50.3 & 63.8 & 9.9 . & 15.4 & 18.9 & 21.3 & 20.6 & 15.7 & 9.0 & -1.7 & 2.5 & 6.0 & 8.1 & 7.6 & 4.0 & 0.5 & Sep 06 \\
\hline Fort Nelson A & 16.7 & 41.7 & 69. & 84.3 & 61.2 & 41.6 & 24.3 & 7.9 & 16.2 & 20.7 & 2 & 21.0 & 14.5 & 6.2 & -4 & 3.0 & 8.0 & 10.4 & 8.6 & 2.8 & -4.1 & Sep 09 \\
\hline Prince & 27.4 & 47.3 & 66.9 & 59.7 & 68.2 & 58.7 & 59.2 & 10.3 & 16.1 & 19.5 & 22.0 & 20.8 & 15.9 & 9.6 & -1.7 & 2.5 & 6.2 & 8.1 & 7.2 & 3.5 & -0.1 & Aug 31 \\
\hline Farts & 21 & 38.9 & 68.0 & 77.1 & 60.3 & 39.2 & 27.7 & 8.2 & 15.7 & 19.2 & 21 & 20.1 & 14.8 & 8.7 & -2.4 & 3.7 & 7.7 & 99 & 8.7 & 42 & -0.3 & Sep 13 \\
\hline Dawsor & 9.7 & 21.1 & 38 & 47 & 44.0 & 28.2 & 28 . & 5.4 & 14.4 & 20.8 & 22.4 & 19.4 & 11.9 & -0.5 & -8.7 & 0.7 & 6.6 & 8.9 & 6.5 & 1.0 & -7.5 & Aug 28 \\
\hline elkirk & 11 & 19 & 34 & 49 & 33.5 & 24 & & 6.9 & 14.5 & 20.6 & 2 & & 13.3 & 2. & -7.7 & -0.1 & 5.0 & 75 & 4.9 & -0.4 & -7.9 & 17 \\
\hline Watsor & 15.1 & 29. & 51 & 58 & 42.0 & 43.7 & 35 & 6.0 & 13.3 & 18.9 & 21.0 & 19.3 & 12.9 & 4.4 & -7.1 & 0.5 & 6.4 & 8.8 & 7.0 & 2.3 & -4.6 & Sep 04 \\
\hline & 12.3 & 14. & 31. & 41.5 & 32.4 & 22 & 15 & 6.0 & 13.4 & 19.8 & 21 . & 19.1 & 13,1 & 3.1 & -8.8 & -2.1 & 2.8 & 53 & 2.3 & -2.6 & -9.6 & Jul 27 \\
\hline Whiteh & 9.5 & 12.9 & 30.7 & 33.9 & 37.9 & 30.3 & 21 & 5.6 & 12.7 & 18.4 & 20 ? & 18.4 & 12.4 & 4.4 & -5.1 & 0.6 & 5.5 & 7.9 & 6.5 & 2.6 & -3.1 & Aug 30 \\
\hline Carcro & 6. & 11.8 & 15. & 19.2 & 21.2 & 21.8 & 20 & 5.6 & 11.5 & 16.7 & 18 & 17.9 & 12.3 & 5.1 & -5.9 & -0.5 & 4.6 & 6.4 & 4.9 & 1.4 & -3.2 & Aug 17 \\
\hline Snag & 17.9 & 28.9 & 58.3 & 61.1 & 39.0 & 29.0 & 21 & 5.5 & 13.5 & 19.3 & 20. & 18.8 & 11.9 & -0.6 & -9.9 & -0.7 & 4.8 & 7.0 & 4.2 & -1.7 & -11.6 & Aug 10 \\
\hline Fort Smith A & 16.2 & 27.8 & 41.2 & 56.9 & 42.5 & 41.1 & 26 & 4.2 & 14.4 & 20.3 & 22.5 & 20.7 & 12.6 & 4. & -8.6 & 1.2 & 6.8 & 9.5 & 7.6 & 2.3 & -3.9 & Aug 20 \\
\hline Fort Simpson A & 14.6 & 31.1 & 38.7 & 59.3 & 44.8 & 31.3 & 24 & 3.9 & 14.5 & 21.1 & 23.2 & 21.0 & 12.9 & 2. & -8.8 & 1.4 & 7.7 & 10.0 & 7.8 & 1.7 & -6.2 & Aug 21 \\
\hline Wrigl & 17. & 27 . & 43.5 & 54. & 46. & 30. & 32 . & 2.7 & 13.7 & 20.7 & 22.8 & 20.1 & 11.6 & 0.0 & -9.9 & 0.8 & 7.4 & 9.8 & 7.5 & 1.5 & -7.1 & Aug 17 \\
\hline Hay River A & 15.8 & 20.1 & 26.8 & 48.1 & 37.7 & 42.3 & 30.5 & 1.5 & 10.8 & 17.2 & 20.7 & 19.4 & 12.4 & 4.8 & -9.9 & 0.4 & 6.5 & 10.8 & 9.3 & 3.7 & -2.9 & Sep 11 \\
\hline
\end{tabular}

$\mathrm{A}=$ airpon.

$E=$ estimated

TABLE 4. $2 \times \mathrm{CO}_{2}$ Estimated mean monthly climate data

\begin{tabular}{|c|c|c|c|c|c|c|c|c|c|c|c|c|c|c|c|c|c|c|c|c|c|c|}
\hline \multirow[b]{2}{*}{ Site } & \multicolumn{7}{|c|}{ Precipitation (mm) } & \multicolumn{7}{|c|}{ Maximum temperature $\left({ }^{\circ} \mathrm{C}\right)$} & \multicolumn{7}{|c|}{ Minimum temperature $\left({ }^{\circ} \mathrm{C}\right)$} & \multirow[b]{2}{*}{ Frost } \\
\hline & Apr & May & Jun & Jul & Aug & Sep & Oct & Apr & May & Jun & Jul & Aug & Sep & Oct & Apr & May & Jun & $\mathrm{Jul}$ & Aug & Sep & $\overline{\mathrm{Oct}}$ & \\
\hline$\overline{\text { itka }}$ & $\overline{0.1}$ & 8.2 & $0 \overline{7.9}$ & $\overline{91.2}$ & $\overline{2.2}$ & 9.4 & $\overline{392.4}$ & 1.9 & $\overline{20.2}$ & 2.2 & 8 & 19.3 & $\overline{17.1}$ & $\overline{13.7}$ & .1 & $\overline{13.1}$ & $\overline{5}$ & $\overline{14.4}$ & $\overline{14.2}$ & 1.3 & $\overline{7.7}$ & Tov 14 \\
\hline watat & & 0.7 & 15.8 & 194.5 & 05.2 & 72.5 & 66.8 & 06 & 13.4 & 16.9 & 2.0 & 18.9 & 6 & 115 & .7 & 5.7 & 10.0 & 12.3 & 11.4 & 8.3 & 4.5 & \\
\hline chorag & .6 & 14.5 & 32.2 & 54.0 & 48.9 & 78.4 & 60.3 & 6.9 & 18.5 & 21.2 & 22.2 & 20.8 & 16.1 & .4 & 6 & 8.8 & 12.9 & 0 & .4 & 3 & 0.1 & $30 \mathrm{E}$ \\
\hline ti & 0.8 & 8.5 & 84.7 & 135.2 & 119.6 & 207.8 & 332.8 & 10.2 & 13.0 & 17.4 & 9.1 & 19.9 & 17.1 & 121 & .4 & 7.2 & 10.3 & 2.9 & 13.1 & 10.4 & 5.4 & \\
\hline reka Lod & 2.1 & 28.7 & 78.3 & 89.9 & 59.4 & 41.1 & 32.2 & 2.2 & 13.2 & 25.2 & 1.0 & 18.5 & 12.5 & 2.7 & -7.5 & 4.5 & 12.7 & 10.6 & 8.6 & 3.2 & -6.7 & \\
\hline & & 24.4 & 91.0 & 101.1 & 65.8 & & 30.6 & 4.8 & 15.4 & 22.8 & .2 & & 13.5 & 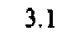 & & 2.9 & 9.3 & & 1 & .9 & -5.1 & \\
\hline & & 16.7 & 40.6 & 74.9 & 67.1 & 6 & 53.7 & 6.2 & 18.0 & 27.4 & & & 15.3 & & & 7.0 & .0 & 15.6 & 12.1 & .8 & -4.0 & \\
\hline llingham & 30.5 & 31.8 & 40. & 89.0 & 117.9 & 137.9 & 95.3 & 8.5 & 15.5 & 21.1 & 2.8 & 21.7 & 17.5 & 9.7 & .4 & 6.6 & 10.5 & 12.9 & 2.7 & .8 & 1.6 & \\
\hline & & & & 53.3 & & & & 3.9 & & & & & & & 50 & 7.1 & 12.5 & & & .0 & -4.4 & \\
\hline lakleet & & 3 & 37 & 71 & 8. & & 28 & 4.5 & 16.5 & & & 18.3 & 13. & 4.8 & -0.4 & 8.8 & 9. & & & 5.4 & -3.6 & \\
\hline & & 20.3 & 34 & 53. & 87.9 & & 32.8 & -0.2 & & & & & & & & & & & & .4 & -4.6 & \\
\hline & 0.4 & 0 & & , & 25.7 & & 12 & 1.3 & 4.7 & & & 14 & 14.3 & 6.8 & -2.0 & -1.8 & 7.3 & & & 2.8 & 0.8 & \\
\hline 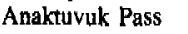 & & 15. & & & 45. & & 19 & -7.6 & 6.0 & & & 14 & 6.0 & -5.2 & -18.2 & -3.1 & 11.0 & . & 5 & -2.3 & -9.4 & \\
\hline & & 4. & & & 42.8 & & 15 & -8.8 & 2.0 & & & & & -2.8 & & -4.5 & .7 & & & -0.2 & -7.6 & \\
\hline 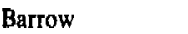 & 7.3 & 5. & 1 & & 35.5 & 19.5 & 16.0 & -9.4 & -1.0 & 2 & 2 & 9.3 & 4.7 & -2.8 & .5 & -4.6 & 7.1 & & & 2 & -4.0 & \\
\hline & & 61.1 & & & 770 & & & 9.3 & & & & & 17.9 & 13.4 & & & & & & & 1.4 & \\
\hline & & 3 & & 7 & 38.1 & 42 & 34 & 8.5 & & & & & 17.2 & & & & & & & .2 & -0.8 & \\
\hline & & & & & a & & & 15.6 & & & & & & & & & & & & & 4 & \\
\hline & & & & & 04 & & & 8.8 & & 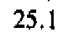 & & & & & & & & & & 2 & -2.2 & \\
\hline & & & & & 78.8 & & 62.8 & 14.0 & 23.0 & 4 & & & 18.4 & 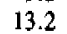 & 4 & 2 & & & & 1 & 2.5 & \\
\hline & & & & & 60 & & 36 & 0 & & & & & & & & & & & & & 1.7 & \\
\hline & & & & & 62.0 & & & 7. & & & & & & & & & & & & 0 & -4.5 & \\
\hline & & & & & & & & 8.1 & & & & & & & & & & & & & & \\
\hline & & 30 & & 68 & 4 & & 42 & 6. & & & & & & & & & & & 10 & 1 & -3.2 & \\
\hline & & & & 46 & 34 & & & 6 & & & & & & & & & & & & & -8.2 & \\
\hline & & & & & & & & & & & & & & & & & & & & & -1.6 & \\
\hline 10 & 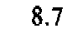 & 10. & & & 23.8 & & 23 & 6. & 14.0 & & & & 15 & & & & & & & 4 & -1.7 & \\
\hline & & & & & 46 & & & 6 & & 28.7 & & & & 2 & & & & & & 1.4 & -9.8 & \\
\hline & & & & 49 & 40 & & & 4. & & 24 & & 23 & 15 & 7 & & & & & & 5.7 & -2.1 & \\
\hline & & 31. & 40 & & 56 & & 29 & 4.3 & 17.6 & 24 & & 23 & 15 & 3 & & & & & & 5.3 & -4.4 & \\
\hline & & & & & 60 & & 35 & 3. & & 24 & & 22 & & 2 & & & & & & 7 & -5.7 & \\
\hline Hay River $A$ & 18.2 & 19.0 & 22.9 & 46.2 & 41.2 & 45.3 & 44.3 & 2.5 & 13.9 & 21.1 & 23.3 & 22.5 & 11.6 & 7.5 & -8.7 & 3.0 & 10.8 & 14.6 & 13.3 & 7.1 & 0.9 & Sep $26 \mathrm{E}$ \\
\hline
\end{tabular}

$A=$ airport.

$E=$ estimated 
be seen, the decision to place soil series in the lower class when there was a choice of 2 classes has resulted in excessive quantities of class 5 and class 7 soils at the detriment of classes 4 and 6 . When compiled in this way the soil resources represent a very substantial land area easily equal to other large agricultural regions of Canada. Currently, there are over $15 \mathrm{M} \mathrm{Ha}$ of potentially arable land in the Canadian portion of the study area and over $41 \mathrm{M} \mathrm{Ha}$ in Alaska, for a total of over $57 \mathrm{M}$ Ha of identified land with agricultural potential for use in either annual cropping or perennial forage systems. Of particular note are the areas of southern and interior Alaska and northern Alberta. By comparison, the 1981 Canadian Census of Agriculture (Statistics Canada, 1982) showed the total area of farms in Canada to be $65.8 \mathrm{M}$ $\mathrm{Ha}$. Of this, 46.1 M Ha were classed as improved land and 38.6 M Ha of that were in the four western provinces.
While Table 5 identifies very large areas of potentially arable land, it should be pointed out that this may still be an underestimation of the total area available. This table reflects only those areas that have been soil surveyed and for which the soil survey specifically assessed the land capability for agriculture (Fig. 1). There are large areas that have either not been surveyed to date or, particularly in British Columbia, where several surveys were even more exploratory in nature, the surveys simply listed the soil series present with no assessment of their suitability for agriculture or other uses. These areas have not been included in this summary. Also, in many surveys and assessment systems the soil survey personnel intrinsically incorporated a perceived climate or climatic restrictions into the soil capability for agriculture. It would appear that these perceptions were often based on more southern agricultural practices, and this has resulted

TABLE 5. Proportionment of potentially arable soils for major land resource areas

\begin{tabular}{|c|c|c|c|c|c|c|c|c|}
\hline \multirow[b]{2}{*}{ Major land resource area } & \multicolumn{6}{|c|}{ Potential arable soil area (ha) } & \multirow[b]{2}{*}{ Total (1-5) } & \multirow[b]{2}{*}{ MLRA total } \\
\hline & Class $1-2$ & Class 3 & Class 4 & Class 5 & Class 6 & Class 7 & & \\
\hline $\begin{array}{l}\text { Southern Alaska } \\
\text { *Southeastern Alaska } \\
\text { *South central Alaska mountains } \\
\text { Cook Inlet - Susitna lowland } \\
\text { *Alaska Peninsula and southwestern islands }\end{array}$ & $\begin{array}{r}2023 \\
11331 \\
507898 \\
-\end{array}$ & $\begin{array}{r}4451 \\
102793 \\
260626 \\
12141\end{array}$ & & 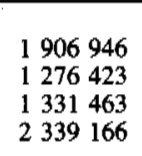 & & $\begin{array}{r}5671870 \\
10767852 \\
867676 \\
6816362\end{array}$ & $\begin{array}{l}1913420 \\
1390547 \\
2099987 \\
2351307\end{array}$ & $\begin{array}{rll}7 & 585 & 290 \\
12 & 158 & 399 \\
2 & 967 & 663 \\
9 & 167669\end{array}$ \\
\hline $\begin{array}{l}\text { Interior Alaska } \\
\text { *Copper River plateau } \\
\text { *Alaska Range } \\
\text { Interior Alaska lowlands } \\
\text { *Kuskokwim highlands } \\
\text { Interior Alaska highlands }\end{array}$ & $\begin{array}{r}7689 \\
16997 \\
3514819 \\
1054243 \\
1582781\end{array}$ & $\begin{array}{r}142049 \\
3237 \\
367872 \\
464190 \\
167950\end{array}$ & & 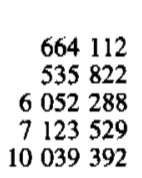 & & $\begin{array}{rrr}2 & 828 & 043 \\
7 & 117 & 863 \\
2 & 432 & 247 \\
10 & 308 & 518 \\
9 & 835 & 019\end{array}$ & $\begin{array}{r}813850 \\
556056 \\
9934979 \\
8641962 \\
11790123\end{array}$ & $\begin{array}{rrr}3 & 641 & 893 \\
7 & 673 & 919 \\
12 & 367 & 226 \\
18 & 950 & 480 \\
21 & 625 & 142\end{array}$ \\
\hline $\begin{array}{l}\text { Arctic and western Alaska } \\
\text { *Norton Sound highlands } \\
\text { **Western Alaska coastal plains and deltas } \\
\text { **Bering Sea islands } \\
\text { **Brooks Range } \\
\text { **Arctic foothills } \\
\text { **Arctic coastal plain }\end{array}$ & $\begin{array}{c}59086 \\
809 \\
- \\
- \\
- \\
-\end{array}$ & $\begin{array}{c}25497 \\
- \\
- \\
- \\
-\end{array}$ & & $\begin{array}{r}963186 \\
869700 \\
10117 \\
10117 \\
6879 \\
-\end{array}$ & & $\begin{array}{r}11469602 \\
6589730 \\
1053838 \\
11790529 \\
12736313 \\
4987 \\
4118\end{array}$ & $\begin{array}{r}1047769 \\
870509 \\
10117 \\
10117 \\
6879 \\
-\end{array}$ & $\begin{array}{rrr}12 & 517 & 371 \\
7 & 460 & 239 \\
1 & 063 & 955 \\
11 & 800 & 646 \\
12 & 743 & 192 \\
4 & 987 & 118\end{array}$ \\
\hline $\begin{array}{l}\text { Alberta } \\
\text { Upper Peace } \\
\text { Lower Peace }\end{array}$ & $\begin{array}{l}1951609 \\
1346191\end{array}$ & $\begin{array}{r}1331717 \\
194077\end{array}$ & $\begin{array}{r}1541184 \\
789423\end{array}$ & $\begin{array}{r}2525013 \\
759120\end{array}$ & 253289 & $\begin{array}{l}11379366 \\
16729003\end{array}$ & $\begin{array}{l}7349523 \\
3088811\end{array}$ & $\begin{array}{lll}18 & 728 & 889 \\
20 & 071 & 103\end{array}$ \\
\hline $\begin{array}{l}\text { British Columbia } \\
\text { North central interior } \\
\text { Northern B.C. - Ft. Nelson, Liard } \\
\text { Prince George } \\
\text { Peace }\end{array}$ & $\begin{array}{c}14771 \\
-\overline{-} \\
91 \overline{9}\end{array}$ & $\begin{array}{r}92959 \\
6552 \\
20828 \\
150332\end{array}$ & $\begin{array}{rl}171 & 228 \\
51 & 722 \\
53 & 214 \\
487 & 209\end{array}$ & $\begin{array}{r}118779 \\
33333 \\
178421 \\
451852\end{array}$ & $\begin{array}{c}496931 \\
- \\
43 \overline{119}\end{array}$ & $\begin{array}{l}147796 \\
216737 \\
350525 \\
146585\end{array}$ & $\begin{array}{r}397737 \\
91607 \\
252463 \\
1181368\end{array}$ & $\begin{array}{r}1042464 \\
308344 \\
602988 \\
1371072\end{array}$ \\
\hline $\begin{array}{l}\text { Yukon } \\
\text { Klondike Plateau (Dawson) } \\
\text { Lewes Plateau (Carmacks) } \\
\text { Liard plain (Watson Lake) } \\
\text { *Pelly plateau (Ross River) } \\
\text { Teslin plateau (Whitehorse) } \\
\text { *Takhini - Dezadeash } \\
\text { *Wellesley Basin (Snag) }\end{array}$ & $\begin{array}{l}- \\
- \\
- \\
- \\
-\end{array}$ & $\begin{array}{l}- \\
- \\
- \\
- \\
- \\
-\end{array}$ & $\begin{array}{c}24380 \\
27730 \\
10447 \\
644 \\
- \\
- \\
-\end{array}$ & $\begin{array}{r}16912 \\
143721 \\
209267 \\
31912 \\
73240 \\
126215 \\
35821\end{array}$ & $\begin{array}{r}17238 \\
17127 \\
267 \\
67235 \\
17472 \\
14887 \\
2018\end{array}$ & $\begin{array}{rr}13 & 613 \\
67 & 691 \\
97 & 737 \\
12 & 768 \\
79 & 278 \\
26 & 178 \\
17 & 766\end{array}$ & $\begin{array}{r}41292 \\
171451 \\
219714 \\
32556 \\
73240 \\
126215 \\
35821\end{array}$ & $\begin{array}{r}72143 \\
256269 \\
317718 \\
112559 \\
169990 \\
167280 \\
55605\end{array}$ \\
\hline $\begin{array}{l}\text { Northwest Territories } \\
\text { Slave River lowlands } \\
\text { Liard Valley and upper Mackenzie } \\
\text { Mackenzie River } \\
\text { Hay River }\end{array}$ & $\begin{array}{c}160787 \\
- \\
- \\
-\end{array}$ & $\begin{array}{r}478517 \\
292799 \\
231286 \\
19337\end{array}$ & $\begin{array}{r}148 \overline{072} \\
318256 \\
4786\end{array}$ & $\begin{array}{r}47066 \\
449019 \\
262367 \\
109615\end{array}$ & $\begin{array}{c}- \\
87554 \\
- \\
-\end{array}$ & $\begin{array}{r}144073 \\
278067 \\
942789 \\
123635\end{array}$ & $\begin{array}{l}686370 \\
889890 \\
811909 \\
133738\end{array}$ & $\begin{array}{r}830443 \\
1255511 \\
1754698 \\
257373\end{array}$ \\
\hline
\end{tabular}

Total

Not restricted

Current climate restricted

$10323009 \quad 4369210 \quad 3628295 \quad 38700813$

$9170831 \quad 3614852 \quad 3627651 \quad 22800868$

1017137

$10314511 \quad 4227161 \quad 3628295$

37146767

932997

136046187

43851837

57021327

$2 \times \mathrm{CO}_{2}$ climate restricted

$1017137 \quad 108796929$

55316734

*MLRAs removed by current climate restrictions.

* MLRAs removed by $2 \times \mathrm{CO}_{2}$ climate restrictions. 
in downgrading of many areas that have adequate soils from their real capability. The areas shown in Table 5 are the total gross areas from the respective surveys. These areas have not been adjusted for losses due to rights-of-way, lakes, drainage patterns or activities such as habitat protection or land claims. In spite of these factors and the class placement problem, these areas should be considered as reasonable estimates.

\section{Current Climate Resources}

The climate capability ratings, effective growing degree days and effective moisture stress for each site are shown as the $1 \times \mathrm{CO}_{2}$ environment in Table 6. From this it is clear that a wide range of climatic capability exists within the study area. The results shown in Table 6 indicate that a number of MLRAs were identified as being limited by the current climate and hence were deemed non-arable. This reduced the currently potential area from more than $57 \mathrm{M} \mathrm{Ha}$ to just over $39 \mathrm{M}$ Ha through climate considerations (Table 5). The study area is classified as having an overall average class 5 (primarily heat limited) climate. This ranges from a class 2 to a class 7 due to the wide range of conditions present in each of the sub-regions. The currently available $39 \mathrm{M} \mathrm{Ha}$ of arable land area can be broken down to $23.8 \mathrm{M} \mathrm{Ha}$ in Alaska and 15.3 M Ha in Canada. Despite extensive agricultural industry in other parts of both countries, development within the study area has been slow. This can be attributed to the effects of small or distant markets and poorly developed infrastructures.

TABLE 6. Climate capability ratings

\begin{tabular}{|c|c|c|c|c|c|c|}
\hline \multirow[b]{2}{*}{$\underline{\text { Site }}$} & \multicolumn{3}{|c|}{$1 \times \mathrm{CO}_{2}$ environment } & \multicolumn{3}{|c|}{$2 \times \mathrm{CO}_{2}$ environment } \\
\hline & Energy (EGDD) & Moisture deficit (mm) & Class & Energy (EGDD) & Moisture deficit (mm) & Class \\
\hline $\begin{array}{l}\text { Southern Alaska } \\
\text { Sitka } \\
\text { Yakutat } \\
\text { Anchorage } \\
\text { Kodiak }\end{array}$ & $\begin{array}{r}1005 \\
677 \\
970 \\
762\end{array}$ & $\begin{array}{r}305.8 \\
726.0 \\
-157.0 \\
283.3\end{array}$ & $\begin{array}{l}6 \mathrm{H} \\
7 \mathrm{H} \\
5 \mathrm{H} \\
7 \mathrm{H}\end{array}$ & $\begin{array}{l}1855 \\
1282 \\
1705 \\
1404\end{array}$ & $\begin{array}{r}249.0 \\
663.2 \\
-263.4 \\
256.3\end{array}$ & $\begin{array}{l}1 \mathrm{M} \\
3 \mathrm{H} \\
2 \mathrm{M} \\
2 \mathrm{H}\end{array}$ \\
\hline $\begin{array}{l}\text { Interior Alaska } \\
\text { Eureka Lodge } \\
\text { McKinley Park } \\
\text { Fairbanks } \\
\text { Dillingham } \\
\text { Hughes }\end{array}$ & $\begin{array}{r}411 \\
587 \\
1152 \\
723 \\
946\end{array}$ & $\begin{array}{r}-51.4 \\
-159.6 \\
-292.4 \\
-58.5 \\
-276.8\end{array}$ & $\begin{array}{l}7 \mathrm{H} \\
6 \mathrm{H} \\
3 \mathrm{H} \\
7 \mathrm{H} \\
5 \mathrm{H}\end{array}$ & $\begin{array}{l}1237 \\
1210 \\
1835 \\
1598 \\
1609\end{array}$ & $\begin{array}{l}-132.9 \\
-147.7 \\
-318.1 \\
-126.7 \\
-300.9\end{array}$ & $\begin{array}{l}2 \mathrm{H} \\
2 \mathrm{H} \\
3 \mathrm{M} \\
1 \mathrm{M} \\
3 \mathrm{M}\end{array}$ \\
\hline $\begin{array}{l}\text { Arctic and Western } \\
\text { Unalakleet } \\
\text { Bethel } \\
\text { Mekoryuk } \\
\text { Anaktuvuk Pass } \\
\text { Umiat } \\
\text { Barrow }\end{array}$ & $\begin{array}{r}587 \\
661 \\
309 \\
281 \\
358 \\
0\end{array}$ & $\begin{array}{r}-12.2 \\
-70.3 \\
-172.1 \\
-140.1 \\
-253.8 \\
31.4\end{array}$ & $\begin{array}{l}7 \mathrm{H} \\
6 \mathrm{H} \\
7 \mathrm{H} \\
7 \mathrm{H} \\
7 \mathrm{H} \\
7 \mathrm{H}\end{array}$ & $\begin{array}{r}1279 \\
659 \\
550 \\
860 \\
968 \\
278\end{array}$ & $\begin{array}{r}-68.1 \\
-70.3 \\
-240.1 \\
-160.9 \\
-296.0 \\
-30.4\end{array}$ & $\begin{array}{l}2 \mathrm{H} \\
6 \mathrm{H} \\
6 \mathrm{H} \\
6 \mathrm{H} \\
5 \mathrm{H} \\
7 \mathrm{H}\end{array}$ \\
\hline $\begin{array}{l}\text { Alberta } \\
\text { Beaverlodge } \\
\text { Fort Vermilion }\end{array}$ & $\begin{array}{l}1070 \\
1202\end{array}$ & $\begin{array}{l}-228.4 \\
-296.1\end{array}$ & $\begin{array}{r}4 \mathrm{H} \\
2 \mathrm{M}\end{array}$ & $\begin{array}{l}1791 \\
1787\end{array}$ & $\begin{array}{l}-327.6 \\
-371.0\end{array}$ & $\begin{array}{l}3 \mathrm{M} \\
3 \mathrm{M}\end{array}$ \\
\hline $\begin{array}{l}\text { British Columbia } \\
\text { Smithers A } \\
\text { Fort Nelson A } \\
\text { Prince George A } \\
\text { Fort St. John A }\end{array}$ & $\begin{array}{l}1042 \\
1181 \\
1053 \\
1134\end{array}$ & $\begin{array}{l}-337.8 \\
-202.3 \\
-264.7 \\
-174.8\end{array}$ & $\begin{array}{l}4 \mathrm{H} \\
3 \mathrm{H} \\
4 \mathrm{H} \\
3 \mathrm{H}\end{array}$ & $\begin{array}{l}1733 \\
1842 \\
1814 \\
1759\end{array}$ & $\begin{array}{l}-413.3 \\
-256.1 \\
-365.2 \\
-249.7\end{array}$ & $\begin{array}{l}4 \mathrm{M} \\
2 \mathrm{M} \\
3 \mathrm{M} \\
2 \mathrm{M}\end{array}$ \\
\hline $\begin{array}{l}\text { Yukon Territory } \\
\text { Dawson } \\
\text { Fort Selkirk } \\
\text { Watson Lake } \\
\text { Ross River } \\
\text { Whitehorse A } \\
\text { Carcross } \\
\text { Snag A }\end{array}$ & $\begin{array}{l}974 \\
836 \\
911 \\
557 \\
826 \\
594 \\
681\end{array}$ & $\begin{array}{l}-346.8 \\
-393.9 \\
-256.8 \\
-439.1 \\
-333.9 \\
-377.3 \\
-280.8\end{array}$ & $\begin{array}{l}4 \mathrm{H} \\
5 \mathrm{H} \\
5 \mathrm{H} \\
6 \mathrm{H} \\
5 \mathrm{H} \\
6 \mathrm{H} \\
6 \mathrm{H}\end{array}$ & $\begin{array}{l}1675 \\
1675 \\
1516 \\
1242 \\
1608 \\
1369 \\
1503\end{array}$ & $\begin{array}{l}-381.3 \\
-490.0 \\
-289.5 \\
-498.8 \\
-399.1 \\
-459.2 \\
-373.0\end{array}$ & $\begin{array}{l}4 \mathrm{M} \\
5 \mathrm{M} \\
3 \mathrm{M} \\
5 \mathrm{M} \\
4 \mathrm{M} \\
5 \mathrm{M} \\
4 \mathrm{M}\end{array}$ \\
\hline $\begin{array}{l}\text { Northwest Territorie } \\
\text { Fort Smith A } \\
\text { Fort Simpson A } \\
\text { Wrigley A } \\
\text { Hay River A }\end{array}$ & $\begin{array}{r}1049 \\
1119 \\
1053 \\
959\end{array}$ & $\begin{array}{l}-324.9 \\
-330.2 \\
-313.1 \\
-254.9\end{array}$ & $\begin{array}{l}4 \mathrm{H} \\
3 \mathrm{H} \\
4 \mathrm{H} \\
5 \mathrm{H}\end{array}$ & $\begin{array}{l}1614 \\
1661 \\
1642 \\
1430\end{array}$ & $\begin{array}{l}-410.8 \\
-290.8 \\
-395.7 \\
-314.5\end{array}$ & $\begin{array}{l}4 \mathrm{M} \\
3 \mathrm{M} \\
4 \mathrm{M} \\
3 \mathrm{M}\end{array}$ \\
\hline Averages & 802 & -170.4 & 5.2 & 1437 & -227.3 & 3.5 \\
\hline
\end{tabular}

$\mathrm{A}=$ airport. 


\section{The Effects of Climatic Change}

The GCM showed average increases in the April-October minimum and maximum temperatures for all sites of $4.06^{\circ} \mathrm{C}$ and $3.58^{\circ} \mathrm{C}$ respectively. Precipitation for the same period was shown to increase by an average of $16.6 \%$ for all sites. The use of long-term climatic data and the output from the GCM as input into the CCS software allowed the determination of climatic capability ratings for both the current climate and that projected to exist given a $2 \times \mathrm{CO}_{2}$ environment (Table 6).

The $2 \times \mathrm{CO}_{2}$ climate shows a very significantly warmer and somewhat drier environment, with overall increased moisture deficits and improved climatic capability ratings. As a result of the changed climate the overall energy term has increased approximately $75 \%$, the moisture deficit has increased by approximately $60 \mathrm{~mm}$ and the study area's overall average capability rating has risen from class 5.2 (primarily heat limited) to class 3.5 (primarily moisture limited) (Table 6). The area of potentially arable soils increased significantly from just over $39 \mathrm{M} \mathrm{Ha}$ with the current climate restrictions to more than $55 \mathrm{M} \mathrm{Ha}$ with the $2 \times \mathrm{CO}_{2}$ climate restrictions and is only slightly lower than the total area without climate restrictions (Table 5). These changes have resulted in an increase in the usable arable soil area of approximately $16 \mathrm{M} \mathrm{Ha}$. The majority of this increase is in Alaska, where the arable land area increases from $23.8 \mathrm{M} \mathrm{Ha}$ to $39.7 \mathrm{M} \mathrm{Ha}$, while the Canadian portion increases from $15.3 \mathrm{M} \mathrm{Ha}$ to $15.5 \mathrm{M} \mathrm{Ha}$. This area would be capable of supporting a much expanded agricultural industry, particularly in northern Alberta, British Columbia and the southern portions of Alaska, where a greater infrastructure currently exists. There are numerous other related questions that must be answered before this can happen. Principal among these are the questions relating to the adaptation of our existing plant species and varieties to a higher $\mathrm{CO}_{2}$ and the longer photoperiod environment that will be found with latitudinal adaptation.

Given the very large spatial extent of the study area, the range of $2 \times \mathrm{CO}_{2}$ climate data was not particularly large. This can be seen as a resolution problem attributable to both differences in scale between the sites within the study area and the GCM grid cell dimensions, as well as the lack of soil survey areas at higher elevations. An obvious improvement could be made through the use of a third-generation GCM with smaller nested cells over the study area. Such third-generation data would not be expected to change the basic results of this study; however it might provide improved resolution among or within the various MLRAs.

\section{CONCLUSIONS}

The problem of determining and adopting universally acceptable criteria for use in the assessment of soil capability for agriculture still needs to be addressed. As may be clearly seen from the data presented here, and in light of the potential for a changing climate, the practice of biasing the soil rating with a qualitative climate assessment has historically led to improper interpretations. A preferable system is the assessment of the soil and climate resources separately, allowing end-users to reach their own conclusions with regard to which is the most limiting. Such an evaluation tool in the form of the Climate Classification System has been shown to be effective. However, additional development is warranted. Such development should include additional verification for areas outside Alberta and the development of a forage production rating given the large areas of class 4 and 5 land in the study area. An improved understanding of the crop species and varietal responses to photoperiod and the general climate/soil interactions of the areas covered by this study would allow improved resolution and confidence in these results.

There are in excess of $57 \mathrm{M}$ Ha of potentially arable soil resources within the study area. This is approximately $29 \%$ of the total study area and represents all the currently identified areas without, as far as possible, restrictions due to climate, infrastructure or other factors. When the current climate for these areas is overlaid, this area reduces to approximately $39 \mathrm{M} \mathrm{Ha}$, or approximately $68 \%$ of the potentially arable area. This is comparable to an area slightly less than all agricultural land currently in use in Canada east of Saskatchewan. Under the $2 \times \mathrm{CO}_{2}$ climate, an area of over $55 \mathrm{M}$ Ha would be arable, representing an increase of approximately $16 \mathrm{M} \mathrm{Ha}$ due to the changed climate. This represents approximately $97 \%$ of the total potential area. This total area is close to what is currently in use on the entire Canadian prairies (Statistics Canada, 1982). While this represents a significant potential addition to North America's agricultural land base, it is anticipated that there would be some corresponding loss of land base due to moisture limitations. These losses would be expected to occur in areas of the southern Canadian prairies or parts of the continental United States, where moisture is currently limiting and fallow cropping is an accepted practice. As a result of increased moisture deficits, agricultural endeavours in a number of these prospective areas will have to consider the use of moisture conservation practices such as zero tillage, fall cereals or the use of fallow land.

\section{REFERENCES}

ALASKA RURAL DEVELOPMENT COUNCIL. 1983. Alaska's agriculture and forestry. Publication No. 3. McNicholas, H.L., ed. Fairbanks: Cooperative Extension Service, University of Alaska, Fairbanks.

ALBERTA AGROMETEOROLOGY ADVISORY COMMITTEE. 1987. Climate rating for arable agriculture in Alberta. Final Report, May 1987. Edmonton: Alberta Agriculture.

ATMOSPHERIC ENVIRONMENT SERVICE. 1982a. Canadian Climate Normals 1951-1980. Vol. 1. Temperature and Precipitation. Ottawa: Canadian Climate Program, Atmospheric Environment Service, Environment Canada.

1982b. Canadian Climate Normals 1951-1980. Vol. 6. Frost. Ottawa: Canadian Climate Program, Atmospheric Environment Service, Environment Canada.

BEATTIE, K.G., BOND, W.K., and MANNING, E.W. 1981. The agricultural use of marginal lands: A review and bibliography. Working Paper No. 13. Ottawa: Lands Directorate, Environment Canada.

CANADA LAND INVENTORY. 1969, Soil capability classification for agriculture. Report No. 2. Ottawa: Department of Regional Economic Expansion.

CANADIAN CLIMATE CENTRE. 1991. Application of the Canadian Climate Centre General Circulation Model output for regional climate impact studies - Guidelines for users. Downsview: Canadian Climate Centre, Atmospheric Environment Service, Environment Canada. 19 p., maps. 
DEPARTMENT OF MINES AND TECHNICAL SURVEYS. 1957. Atlas of Canada. Ottawa.

ELEY, F.J., and FINDLAY, B.F. 1977. The agroclimatic capability of southem portions of the Yukon Territory and MacKenzie District, N.W.T. Atmospheric Environment Service Project Report No. 33.

HARRIS, R.E., CARDER, A.C., PRINGLE, W.L., HOYT, P.B., FARIS, D.G., and PANKIW, P. 1972. Farming potential of the Canadian Northwest. Agriculture Canada Publication No. 1466.

INTERGOVERNMENTAL PANEL ON CLIMATE CHANGE. 1990. Climate change - The IPCC scientific assessment. Houghton, J.T., Jenkins, G.J., and Ephraums, J.J., eds. New York: Cambridge University Press.

MAGILL, B.L., and GEDDES, F., eds, 1988. The impact of climate variability and change on the Canadian Prairies. Symposium/Workshop Proceedings. Edmonton: Alberta Department of the Environment, 412 p.

McFARLANE, N.A., BOER, G.J., BLANCHET, J.-P., and LAZARE, M. 1992. The Canadian Climate Centre second-generation General Circulation Model and its equilibrium climate. Journal of Climate 5(10):1013-1044.

MILLER, C. 1984. Alaska soils with field crop production suitability. Unpubl. ms. Available at USDA Soil Conservation Service, 949 E. 36th Avenue, Suite 400, Anchorage, Alaska 99508-4302, U.S.A.

MILLS, P. 1992. The implementation of an agroclimatic rating system for Alberta for the assessment of agricultural resources and land potential. Final report to the Prairie Farm Rehabilitation Authority under the
Environmental Sustainability Initiative. Publication NRG 92-17. Agriculture Canada Research Station, Beaverlodge, Alberta.

NATIONAL OCEANIC AND ATMOSPHERIC ADMINISTRATION. 1988. Freeze/frost data: Climatography of the U.S. No. 20, Supplement No. 1. Ashville, N.C.: National Climatic Data Centre, 186 p., maps, appendices.

NORTHERN RESEARCH GROUP. 1978. An assessment of the agricultural potential of the Slave River lowlands of Northwest Territories, Canada. Pringle, W.L., ed. Revised ed. Beaverlodge, Alberta: Agriculture Canada.

RIEGER, S. 1974. Alaska's agricultural potential "soils." Alaska Rural Development Council Publication No. 1. Fairbanks: Cooperative Extension Service, University of Alaska, and U.S. Department of Agriculture Cooperating.

RIEGER, S, SCHOEPHORSTER, D.B., and FURBUSH, C.E. 1979. Exploratory soil survey of Alaska. Anchorage: United States Department of Agriculture, Soil Conservation Service. 213 p., maps.

ROSTAD, H.P.W., and KOZAK, L.M. 1977. Agricultural potential of selected areas in the Northwest Territories. Saskatoon: Saskatchewan Institute of Pedology. Publication No. S176.

STATISTICS CANADA. 1982. 1981 Census of Agriculture. Ottawa: Statistics Canada.

STORIE, R.E. 1933. An index for rating the agricultural value of soils. California Agriculture Experimental Bulletin 556. Berkeley: University of California. $38 \mathrm{p}$. 